\title{
A DOCUMENTACIÓN GALEGA NO SÉCULO XIII: ASPECTOS PALEOGRÁFICOS E DIPLOMÁTICOS
}

\author{
José Ignacio Fernández de Viana y Vieites
}

Universidad de Granada

O título desta conferencia-lección (¿pode facer un profesor diferenza entre ambas as dúas?) que me propuxeron este verán para pronunciar neste ciclo confeso que o aceptei gustosamente ao momento, sobre todo procedendo de profesores dunha facultade da que sigo considerando a miña universidade a índa que estea a $1.100 \mathrm{~km}$ da súa sede - xa que nela estudei e iniciei o meu labor docente no distante setembro de 1965. Reflexionando logo sobre como montar o tema, vinme, durante algún tempo, agoniado por non saber por onde comezar. En definitiva, metérame nun labirinto do que non sabía saír. Pero axiña caín na conta de algo: levaba falando da escritura e do documento na universidade 40 anos en Galicia, Asturias e Andalucía, e vira a evolución de diversas definicións das ciencias que os estudan, a paleografía e a diplomática, feitas por teóricos, non demasiados, que conduciran a algo que hoxe en día está de moda, falar da historia da escritura e, subsidiariamente, do alfabetismo, e da comunicación e a representación do poder.

Falar ante un público tan variado en idade e formación sobre uns temas tan específicos e, ao mesmo tempo, tan complexos, fai supoñer a presenza de persoas dedicadas a estudos tanto de lingüística como de historia xeral como da do dereito, aínda que é frecuente que na actualidade se concreten case exclusivamente á historia e incluso á da Idade Media. Os plans de estudo cambiaron moito dende os comezos da miña preparación docente ata o momento en que pronuncio esta conferencia, e ata dependendo do lugar no que os que me están escoitando cursaron a carreira. Por fortuna a nosa formación xeral no que se chamaban "letras" foi bastante completa, mercé aos cursos comúns, e nalgúns casos -así acontecía na Universidade de Santiago-, un historiador podía optar a ampliar os seus coñecementos do latín en xeral e adquirir os específicos do medieval ou iniciarse nos do chamado entón galaico-portugués. Nós eliximos o primeiro, entre outras razóns, porque os universitarios comezabamos a falar entre nós xa en galego, non nun galego 
académico senón no normal, que non normalizado, semellante ao que empregaban os habitantes da nosa terra na zona rural. Considerábase unha falta de cultura falar en galego en zona urbana, aínda que moi preto dela, en concreto na carballeira de Santa Susana, fose o único que se oía, agás que os compradores do mercado dos xoves procedesen de alén das nosas fronteiras xeográficas. É máis, incluso galegos de nacemento que exercían a docencia noutras universidades recriminaban a alumnos da nosa terra que ao empregaren a lingua castelá non podían agochar o seu acento galego.

Porén, non tiñamos a posibilidade de adquirir coñecementos de historia do dereito español nin do seu pai, o dereito romano, salvo que se nos contaxiase por ocupar historiadores e xuristas o mesmo edificio. Hoxe si sería factible por ter a opción de matricularse e estudar estas materias nelas como de libre configuración. Indagando cal era o plan de estudos da especialidade de Filoloxía Galega nesta universidade o curso pasado, a única que vin relacionada coa escritura e a documentación escrita foi, nos estudos de Terceiro Ciclo, a que leva o título "Paleografía e filoloxía. Formación e evolución dos sistemas de escritura na Europa Medieval". Pero pregunto para min: ¿algún estudante de dereito matricúlase nalgunha materia de Xeografía e Historia ou de Filoloxía Galega?; ¿e desta en historia do dereito?; e tantas posibles combinacións entre, polo menos, as tres citadas licenciaturas. E nestes momentos estou lembrando os profesores García Ramos e Rodríguez Ennes.

Non podo esquecer as fins das calendas de xaneiro de 1977, cando obtiven a praza de profesor agregado de paleografía e diplomática da Universidade de Oviedo. Na miña memoria $\mathrm{p}$ - ara os máis novos direi que era un memorial que tiña que presentar por septuplicado ao tribunal e defender o que nela figuraba (concepto, método, fontes, historia e programa da materia ou materias) que formaba parte do segundo exercicio, dun total de cincofiguraba unha epígrafe que trataba das relacións entre paleografía e filoloxía, creo que por primeira vez, no que empregara sobre todo o artigo de Emilio Alarcos Llorach (1965) "Representaciones gráficas del lenguaje"1. A permanencia durante un curso académico naquela universidade permitiume coñecelo persoalmente e falar, non tanto como quixera, do tema. Anos máis tarde coincidimos en varias ocasións na de Granada. A última, antes do seu pasamento, foi no aeroporto de Baraxas nunha ocasión en que eu volvía de Santiago a Granada e el ía dar unha conferencia a Vigo. Alí sacou unhas fotografías ou fotocopias dunhas páxinas dun manuscrito dunha obra que transcribira mal nalgunha parte un editor (non lembro nin a obra nin o nome deste último). Quedamos en vernos en Madrid para ver o códice orixinal

1. Cf. José Polo (1999-2000) cun saboroso comentario sobre este traballo. 
e comprobar as que o gran filólogo consideraba malas lecturas. Pero non o puidemos facer porque non chegamos a degustar na capital do reino "uvas espinazas" e atragoáronsenos as supostas inexistentes "unas espinazas"2.

Pero deixemos consideracións particulares e algunhas xerais, non moitas, tratadas por paleógrafos e diplomatistas no congreso que se celebrou hai pouco máis de dous anos en León, Orígenes de las lenguas romances en el reino de León. Siglos $I X$-XII, publicadas a finais de 2004 e das que nos interesan dunha maneira especial algunhas ${ }^{3}$. Case polas mesmas datas, un mes antes, celebrouse en Troyes o XI Congreso Internacional de Diplomática, que tivo como tema La langue des actes, cuxa primeira sección estivo dedicada a "Latin et vernaculaires. Latin-vernaculaire: substitutions et recouvrenents", onde se trata do comezo da utilización das linguas vulgares nos diferentes tipos e ambientes en que se redactan os documentos, e como reflicten que se está traducindo dunha lingua vulgar xa falada había tempo na zona, pero non escrita, a un latín máis ou menos vulgar que logo se traduce a aquela, o que se produce, grosso modo, a partir do século XIII ${ }^{4}$.

2. Cf. a explicación que dá Pascual (1999: 377-387) despois da edición de Brien Dutton (1981) de El martirio de San Lorenzo de Gonzalo de Berceo. Trátase da actualmente chamada uva crespa, uva espiña ou groselleira < lat. UVA SPINA; cf. Brian Dutton (1980); en bttp://www.vallenajerilla.com/obrasberceo/sanlorenzo.htm, aínda se transcribe "unas", igual ca en geocities.com/urunuela1/berceo/berceo1/htm. Dutton apóiase no Libro de Alexandre (estudo e edición de Francisco Marcos Marín 1987: 441), que di: "Trillaua don Agosto las mieses por las eras / auentaaua las paruas alçava las çiueras / yua de los agrazes faziendo u $u$ as ueras / eston fazia outunno sus ordenes primeras", v. 2562 (http://cervantesvirtual.com/servlet/SirveObras/06927218700692766 9790079/).

3. M José Sanz Fuentes (2004): "La lengua de los documentos falsos, siglos XI-XII", aínda que o derradeiro estudado e publicado sexa de 1097. E Roger Wright (2004): "La representación escrita del romance en el Reino de León entre 1157 y 1230".

4. Pódense ler os resumos de todas as comunicacións na edición en liña de L'École nationale des chartes http://elec.enc.sorbonne.fr/sommaire163.html, co texto completo dalgúns dos artigos, namentres non sexan editados todos na revista Archiv für Diplomatik, Schriftsgeschichte, Siegel und Wappenkunde, herdeira dende 1955 de Archiv für Urkundenforschung. Xa, previamente, no "Questionnaire du congrè " ou presentación feita polo seu director Olivier Gouyotjeaannin, di que a escolla das falas empregadas nos documentos non fora tratada dende os manuais de Arthur Giry (1894) en edición anastática de 1975, e de Harry Bresslau (1912-1932²), reimpreso en 1958 e traducido do alemán ao italiano en 1998. Desta sección, a que máis nos interesa, publícanse íntegros na citada páxina web os artigos de Giovanna Nicolaj, "Il volgare nei documenti italiani medievali"; de Silio P. Scalfati, "Latin et langue vernaculaire dans les actes notariés corses XIe-XVe siè le", e menos o de Michael Jones, "The Use of French in Medieval Brittany". Da segunda, é de lectura suxerente o de Michael Zimmermann, "L’histoire médiévale coule-telle de source?"; e da terceira, o de Rehard Härtel, "Anthroponymie et diplomatique". De moita menos transcendencia para o noso interese é o ciclo celebrado entre decembro de 2000 e xuño de 2001, por instancia do Institut de la recherche et d'histoire des textes, do C.N.R.S. francés, baixo a rúbrica Les traductions au Moyen Âge et à la Renaissance; destacaremos os temas tratados na sexta sesión, a penúltima, titulada "Le français et le latin des actes administratifs: échanges linguistiques et rapports de droit", e dentro dela as conferencias de Serge Lusignan, "Les ac- 
Os aspectos paleográficos e diplomáticos da documentación do período abranguen practicamente os reinados de Afonso IX (1188-1230), Fernando III (1230-1252), Afonso X (1252-1284), Sancho IV (1284-1295) e comezos de Fernando IV. Pero non todos eles teñen a mesma importancia tanto dende o punto de vista paleográfico e diplomático coma do lingüístico e xurídico.

Como todos sabemos, o concepto de paleografía cambiou nos últimos 23 anos con bastante rapidez. Durante ese tempo destacaremos dúas, quizais tres, tendencias, dúas delas ligadas a unha tradición secular dos estudos sobre a escritura, a escola chamemos centro-norte europea e a mediterránea: a primeira, que liga a historia da escritura á lingüística dende moi cedo nese binomio palabra / escritura; a segunda, á historia, á resurrección do pasado, viaxando ambas por sucesivos camiños, converxentes unhas veces e outras diverxentes.

A primeira, tras a formulación de examinar textos, na súa transmisión temporal, de erros nas copias de obras doutrinais relixiosas que conduciran ao nacemento de teorías erróneas fronte á ortodoxia relixiosa católica, chega á formulación da escritura como un simple reflexo, non sempre conseguido, da lingua, dun sistema semiótico que dende Saussure ata Hjelmslev, e algún máis, é considerada como o medio de comunicación máis avanzado desa dualidade palabra / escritura. Nesta tendencia xogou un papel decisivo a aparición e posterior desenvolvemento do estruturalismo.

A segunda, despois da análise dunha serie de escrituras de contido xurídico e xurídico-económico, adobado pola vaidade da antigüidade, que desembocou nunha serie de formulacións de tipo antropolóxico, incluso case exentas de toda relación coa palabra, intenta explicar, claro está que con aliño ideolóxico, o por que escribimos, poñendo a base en intereses socio-económicos e contables. E a nova escola italiana historicista formula e posteriormente responde a unha serie de preguntas: ¿quen escribe?, ¿que escribe?, ¿para quén escribe?, en definitiva, ¿cal é a finalidade da escritura?

Unha terceira vía moi recente, aínda que con algúns precedentes, é a consideración da escritura como simple imaxe. Nela a presenza de figuras como Leroi-Gourham levou á dualidade xesto-palabra. O prehistoriador francés cre que as primeiras imaxes debuxadas polo home, por moi realistas que sexan, non foron inspiradas polo real senón que constitúen unha "mitografía", teñen un valor de símbolos, non de substitutos das cousas; por tanto, o xermolo da comunicación escrita está no papel da imaxe. Se se puideron transportar as linguas sobre un soporte visual-gráfico é porque esas figuras 
tiñan xa en si mesmas un poder de semantización. Ata aquí vemos moi ben o nacemento dunha nova concepción da escritura. Pero Leroi non se arrisca a chamarlle escritura, é sinxelamente iso, unha mitografía; para que sexa escritura precisa dunha ruptura, que vén dada polo repartimento deses signos no soporte, que pasa dunha organización primitiva bastante libre espacialmente a unha sucesión lineal estrita. Esta linearidade será o síntoma da asimilación polo grafismo dos dous únicos supostos socioculturais capaces de estruturalo nun sistema e conferirlle unha utilidade social directa: o fonetismo da lingua e a lóxica do razoamento contable. E é aquí onde xa volve Leroi a "caer" no "logocentrismo" típico dos historiadores da escritura occidental: "Non é posible a escritura sen unha perspectiva de eficacia inmediata, isto é, sen palabra nin cálculo" (apud Christin 1995: 12).

E máis recentemente Gelg, que, aínda que reprocha aos filólogos a súa ignorancia da pre e protoescritura porque os signos que utilizan non responden exactamente á lingua, paradoxalmente afirma que "só a adaptación do grafismo ao fonetismo verbal constitúe a verdadeira escritura”. Parece que este autor, que fundamenta o comezo da comunicación gráfica, do grafismo, na existencia dunha especie de "inneismo xestual" que suscitaría tipos de signos espontáneos e idénticos entre si en todas as sociedades humanas é discutible que non teña en conta a diversidade desas sociedades coas súas propias convencións culturais, e que por outra parte descoñeza o que xa descubrira Leroi, que un signo non é nada se non se relaciona co soporte no que se inscribe- - non pode subtraerse a que a lingua, a que o fonetismo sexa a chave da escritura ao dicir que a "imaxe reproduce o real da mesma maneira que a palabra imita o son" (apud Christin 1995: 13).

E aínda máis recente é o libro de Ana María Christin (1995) que incide sobre o mesmo tema da imaxe como base da escritura, ao afirmar que "naceu da imaxe" e que "calquera sistema dende o que sexa considerado, ideográfico ou alfabético, a súa eficacia non procede máis que de si mesma”, e mais "o que non significa que sexa algo que non teña que ver nada coa palabra en tanto que vehículo gráfico dunha palabra”, se ben termina coa rotunda afirmación de que a imaxe ten que considerarse "a referencia última e exclusiva do escrito". Esta autora non só reprocha a Leroi a súa caída no fonetismo e a linearidade na distribución dos signos para establecer o nacemento da verdadeira escritura, senón sobre todo o carácter de eficacia e utilidade (contabilidade) que debe ter unha verdadeira escritura, o que levou a formular o principio de que toda escritura evoluciona cara á sinxeleza e a utilidade, ata tal punto que toda aquela que non siga esas pautas está condenada á morte, á desaparición (a excepción do chinés).

Unamos dúas recentes definicións: a escritura como "expresión de conceptos ou sons con elementos visibles predispostos nunha serie, móbiles, e 
compostos segundo determinadas normas" (Silvio Curto 1989); ou como unha "concepción dun instrumento de comunicación como patrimonio cultural dunha clase no poder que individualiza na comunicación lingüística (falada e escrita) un instrumento do seu dominio baseado na organización (burocrática, escolar, etc.) dunha caste de intelectuais aos que está confiada a tarefa de transmitir unha tradición cultural e a elaboración dos instrumentos de comunicación capaces de consolidar a ideoloxía da clase dominante" (Chomsky 1979).

As tres posturas, e estas dúas definicións, a primeira cunha eminente base gráfica, e a segunda lingüístico-historicista, por simplificar, chámense na práctica, historia da escritura, antropoloxía da escritura, imaxe escrita, gramatoloxía, semiótica da escritura, paleografía, e todos os etcéteras que queiramos, parten da pregunta: ¿por que escribimos?, ¿que foi o que levou o home a inventar a escritura?

O primeiro que temos que considerar ante un documento (que estuda a ciencia chamada diplomática, e máis se é do século xiII, que encerraba un valor administrativo e non histórico ao ser posto por escrito ${ }^{5}$ ) son os seus caracteres externos, definidos pola Comisión Internacional de Diplomática como "os elementos de forma que non poden ser examinados nin estudados máis que sobre o orixinal ou sobre a súa reprodución exacta: natureza e presentación do soporte, escritura, elementos figurados ou decorativos" ${ }^{6}$. E como quen lles fala ten unha formación histórica latina, parto da diplomática, porque a paleografía nace como unha ciencia auxiliar daquela, obra de Mabillon. Non obstante, como me dirixo fundamentalmente a filólogos dediquei unhas liñas, quizais demasiadas, para demostra-lo interese que sempre lle dei á filoloxía, porque seguimos as normas propostas pola citada comisión?.

Pero tampouco podemos negar a distinta cualificación da documentación segundo partan dunha formación estrictamente histórica i - nsisto na diplomática dos países mediterráneos - ou unha mixta na que se teña tamén en conta o xurídico. Así, temos as dúas máis empregadas da forma documental, a de Theodor von Sickel (1826-1908), creador da Diplomática moderna, sobre todo pola perfección do método diplomático, e a de Auguste Dumas (1932), historiador do dereito, e seguida por moitos diplomatistas

5. Para ver isto con claridade é de particular interese a lectura da obra de Manuel Romero Tallafigo (2002).

6. Commission Internationale de Diplomatique (1997: 45), (a tradución é miña).

7. Como exemplo, as grafías $u$ y $v$ transcríbense $u$ cando teñen valor vocálico e $v$, cando consonántico, "Só os españois teñen o costume de conservar en todos os casos o $u$ nos textos ata o século XII", Commission Internationale de Diplomatique (1984: 43), (a tradución é miña). 
hispanos. O primeiro divide o documento en tres partes principais: protocolo inicial que abarca invocación, intitulación, dirección e salutación- o texto que comprende fórmula (preámbulo, notificación e exposición), dispositivo, cláusula (sanción e corroboración) - e escatocolo que consta de data (tópica, crónica, persoal, histórica), aprecación e validación (subscricións de outorgantes, confirmantes, testemuños e notario; sinaturas e selo. O segundo redúceas a dúas: protocolo que reúne as formas fóra do teor, que á súa vez agrupa as marcas de validación (subscricións, signos, selos) e as marcas de chancelería (soporte, tinta, escritura, lingua e estilo)- formas no teor que encerra as de confianza (invocación, aprecación, corroboración, data) e de cortesía (intitulación, enderezo, salutación) — e texto encabezado polo dispositivo, os accesorios preliminares (notificación, preámbulo, exposición) e seguido polas accesorias (mención de solemnidades e sancións).

Tamén hai que ter en conta que as relacións entre historia do dereito e diplomática son íntimas, aínda que ás veces os campos non se deslindan ben, ata tal punto que obras como a de Brunner (1961) foi considerada unha obra de diplomática, mentres que a de Redlich (1967) se adoita considerar de historia do dereito. A diplomática estuda o documento; a historia do dereito estuda as realidades xurídicas a través das fontes legais, da literatura xurídica e dos documentos nos que quedan fixadas aquelas realidades. A primeira ten como fin a crítica do documento e a valoración do mesmo no contexto histórico, a explicación da súa forma; a segunda, a súa valoración e a súa crítica en tanto que é testemuña da realidade xurídica concreta ou a explicación da súa materia.

Alejandro Pratesi (1979), no seu exemplar manual de diplomática, define o documento obxecto desta ciencia en relación coa forma, intimamente unida ao modo de emisión, coas seguintes palabras: "Documentos públicos son os que, sendo emitidos por unha chancelería, presentan as formas solemnes típicas do documento chanceleresco", mentres que son "documentos privados os redactados fóra da chancelería que non teñen ningún elemento específico de solemnidade" 8 .

Unha vez feitas estas consideracións previas, estudaremos xa na documentación galega do século XIII os aspectos paleográficos e diplomáticos, segundo reza o título desta conferencia. E quizais lle dedicaremos menos tempo ca o que investimos nas explicacións anteriores porque, salvo na parte da lingua dos documentos privados dende o punto de vista diplomático, no de-

8. Non estamos de acordo coa difusa definición que dá dos documentos semipúblicos. 
mais reflectirán as características comúns, primeiro ao reino de León e despois ao de Castela-León.

A escritura, temos que considerala nas súas dúas modalidades, libraria e documental. Ambas están a cabalo da segunda metade do século XII e primeira do XIII, a primeira dentro do chamado ciclo carolino $€-$ omo o demostra, salvo unha excepción, unha serie de testemuños unidos fundamentalmente ao scriptorium compostelán, e menos ao lucense e auriense- - e a segunda dentro da chamada con bo criterio minúscula diplomática, "denominación escorregadiza en ocasións, que pretende recoller os movementos da escritura carolina e o seu desprazamento cara ás primeiras de fractura, que han caracterizar logo a gótica documental"?.

A escritura libraria podémola ver na primeira parte do Tombo $A$ da catedral de Santiago, iniciado en 1129; na Historia Compostelana, quizais escrita contra 1140, perdida e só conservada copia do XIv; no Tombo de Samos, escrito en 1200 (Lucas Álvarez 1986); no Tombo de Celanova, da segunda metade do XII (Andrade Cernadas 1995); nos de Caaveiro, da mesma data (Fernández de Viana y Vieites / González Balasch 1999); en Xubia, de finais do XIII (Montero Díaz 1935); en Toxosoutos, posiblemente de 1289 (Pérez Rodríguez 2004); en Lourenzá, sobre 1266 (Rodríguez González / Rey Caíña 1992: 11-324); no Tumbo Viejo de Lugo, contra 1231 (Fernández de Viana y Vieites 2003-2004: 593-604); no Libro de Aniversarios de Lugo, do xIII, sen poder afinar máis o cuarto (Jiménez Gómez 1987: 161-227); en varios folios do Tombo $A$ da catedral de Santiago que conteñen documentos de Afonso IX, de arredor do ano 1219 (Lucas Álvarez 1998); en varios fragmentos de códices da catedral de Ourense (Duro Peña 1962: 185-212); no Complutense da Biblioteca Nacional de Madrid, ao redor de finais do XII, claramente compostelán, pero atribuído tamén a un escritorio asturiano (Rodríguez Díaz 1998: 21-50); no Corpus Pelagianum do mesmo fondo da citada biblioteca, de fins do XII (Sicart 1981: 89-95).

A documental pode estar en minúscula carolina pura: atopámola primeiro na escola compostelá, obra de Xelmírez; como exemplo temos o documento da fundación do mosteiro de Santa María de Sar, do día 1 de setembro de 1136, e volvémola ver nos últimos anos do pontificado de don Pedro Suárez de Deza na área compostelá en diversos documentos. Pero sobre todo, rexístrase a minúscula diplomática, que se utiliza dende a segunda metade do século XII ata a primeira do XIII. Lucas Álvarez (1991: 450) cualifícaa de

9. Lucas Álvarez (1991: 445-446). Este estudo é o máis serio que existe sobre a escritura en Galicia, no que modifica en parte o que dixera en "Características de la escritura gótica gallega" (Lucas 1950). 
letra esbelta de astiles y caídos largos y curvados; letra $d$ con frecuencia de tipo uncial ligeramente recurvada; letras aisladas y exentas de nexos; hay una ligera tendencia a la movilidad de los astiles a medida que avanza el periodo; letra $g$ muy generosa en la curvatura de su parte inferior; tendencia generalizada a incrementar la fractura interna de los cuerpos de las letras y abreviaturas muy frecuentes pero comunes en el período.

Xa aparece en Santiago en 1162 trazada por Lupus Arie, notario episcopal. E isto sirva xa de avance, porque onde predominará a escritura minúscula diplomática coas súas tres variedades, a caligráfica, a currens ou corrente, e a cursiva, ademais da primixenia, será na documentación notarial. Porque na documentación real haberá unha igualdade de caracteres, tanto no reino de León coma logo no de Castela-León.

A simple minúscula diplomática está moi próxima e case pode identificarse coa carolina, xa que en Galicia aínda convive coa visigótica, aínda que xa moi influída por aquela, ata 1150. A caligráfica, a currens e a cursiva, coexisten no tempo. A primeira distínguese polo seu trazado lento, con hastís altos e baixos bastante desenvoltos, co $d$ uncial con tendencia a curvar o seu hastil con frecuencia, o $b, l$ e $b$ cos seus terminando coa mesma querencia, o $a$ con ollo cerrado ou non, e os baixos do $h, f, p, q, r$, alongándose e curvándose cara á esquerda, o mesmo que o $s$ cando supera a liña da escritura; o $g$ a miúdo non chega a cerrar o ollo e ás veces o alongalo abarca a letra ou letras anteriores. A separación das palabras está feita con toda corrección e espazo suficiente. A currens normalmente tende á fragmentación. A cursiva distínguese por un maior descoido no seu trazado e unha acentuación a cerrarse a parte alta dos hastís do $b, b$ e $l$. Ás veces a separación das palabras é menor ata ao punto de que se non nos fixamos lemos unidas dúas ou máis.

O ciclo gótico iníciao na $2^{\mathrm{a}}$ metade do XIII, incluso pode adiantarse en Galicia ao resto do reino e prolongarase ata mediados do XIV. A libraria xira fundamentalmente ao redor da escola compostelá, no contorno do arcebispo don Berenguel de Landoria; como exemplo, sirvan unhas páxinas dos feitos don Berenguel de Landoria (Díaz y Díaz 1983), escritos sobre o 1340-1350, ou entre ambos os anos, que aparecen unidos ao códice de Salamanca da Historia Compostelana (manuscrito 2658), elaborado alá polo ano 1250. Tamén debeu ser importante a escola ourensá entre o xIII e o xv, en Tui a fins do XIV.

A escritura documental vese dende mediados do XIII coas variantes de caligráfica ou de privilexios e cursiva ou de "albalás", coa currens entre ambas e nalgúns casos prolongándose ata case 1350. Pero o que máis se verá é a man dos notarios, que utilizarán unha escritura variada. As súas formas gráficas van dende as minúsculas diplomáticas sobre todo currens e cursiva, 
pero con apuntamento dos riscos, fractura interna de cada signo, e continuación do $d$ uncial e ondulación de hastís altos e baixos e os baixos característicos do $g$, acentuando a fractura dos últimos exemplares da minúscula diplomática currens, ata a cursiva.

Diplomaticamente a documentación real carece de interese en Galicia, salvo polo seu contido. No resto é igual dende comezos do reinado de Afonso IX ata os cinco primeiros anos de Fernando IV, cando o reino de Galicia formaba parte do reino de León e o de Castela estaba unido a León. Só podemos destacar os chanceleres e o persoal de chancelería, que eran galegos. Así, na primeira época de Afonso IX (1188-1202), encontramos como chanceler relacionado coa nosa terra a Pedro Vela, que xa o fora con Fernando II, foi arcediago de Santiago e rematou como monxe e logo abade de Oseira ${ }^{10}$. Na segunda (1202-1213) figuran dous co mesmo cargo, Fernando, o deán de Santiago e, como vigairo seu entre 1202 e 1203, Pedro Suárez, probablemente sobriño do arcebispo compostelán do mesmo nome (dende febreiro de 1204 ata xuño de 1210 ocupa efectivamente a chancelería), que ó terminar a súa carreira administrativa se retira tamén ao mosteiro de Oseira; e tamén figura como chanceler o cóengo da mesma catedral Xoán Arias, e como notario de Fernando o seu compañeiro de cabido Pedro Pérez. Na terceira (12131230) figura con este título Pedro Pérez, arcediago de Salamanca, mestrescola de Ourense e cóengo compostelán; e o último Bernardo, deán do mesmo cabido e antes chantre, de 1222 ata quizais 1224, quen termina a súa carreira co seu nomeamento como arcebispo da mesma sede, ata 1237 , en que renuncia ao bispado e se retira ao mosteiro de Santa María de Sar.

Con Fernando III van predominar os chanceleres casteláns e leoneses. Segue ocupando a chancelería leonesa dende xullo de 1238 o arcebispo Juan Arias prolongando a súa presenza no cargo ata despois da morte do monarca, pero cun carácter honorífico, sen ter unha gran influenza no monarca nin acompañalo con frecuencia. A castelá estivo varias veces vacante.

Os notarios, segundos oficiais da chancelería, apenas aparecen. Só atopamos o abade de Valladolid, Juan, en 1220 e en 1223, aínda en etapa castelá; xa na castelá-leonesa a Pedro Núñez en 1241, e o bispo de Segovia, Raimundo, entre 1250 e 1252. Dos escribas non coñecemos a súa orixe de nacemento, pois aínda que foron numerosos, parecen predominar con moito os sorianos e segovianos.

10. Tomamos esta referencia de Julio González (1944: 481). Porén, nos abadoloxios do devandito mosteiro así como nos seus documentos, non aparece tendo esa responsabilidade en ningún momento da súa vida; tampouco como simple monxe. Todos os autores posteriores reproducen esa información que non ten a súa xustificación correspondente. Sospeitamos que se dá o mesmo caso, pero simplemente como monxe, con Pedro Suárez. 
É de destacar que Fernando III é o primeiro monarca que emprega o castelán para a redacción dos seus documentos (véxase Ostos Salcedo 2004), en xeral para os de inferior categoría, cartas abertas e sobre todo mandatos, e aínda así só para a parte do texto, non para o protocolo e escatocolo, que case sempre seguen en latín, e tamén para os foros e outras disposicións nas que interveñen os concellos. Na etapa castelá o primeiro orixinal conservado é de xullo de 1223; e na castelán-leonesa, de xaneiro de $1231^{11}$. Con respecto a Galicia, o primeiro texto real en castelán é de marzo de 1247 e os outros cinco que se conservan, incluso o inicial, corresponden a copias.

Con Afonso X o Sabio asistimos a varias novidades pero tamén á consolidación dalgúns trazos xa ensaiados polo seu pai. En primeiro lugar hai que anotar que a finais do reinado de Fernando III non houbo chanceleres de León e Castela nas persoas dos arcebispos de Santiago e Toledo; o seu oficio só estaba en mans dos notarios, o que continúa ata 1255, en que se volve á vinculación inicial aos arcebispos, aínda que só con carácter honorífico, pero con concesión de rendas, sobre todo porque así os mantiña dentro da "maquinaria" estatal, toda vez que ocuparon ese cargo persoas de extrema confianza e incluso da familia real. Ademais enmárcase no ámbito do oficio público, no que concorren dúas circunstancias: a idea teocrática da monarquía e a mal chamada recepción do dereito romano, segundo vemos polos textos nas Partidas (2.1.5) e outros. Afonso X concibe a chancelería como un mecanismo de centralización e de intervencionismo rexio sen limitacións. Por tanto, a súa función era a de ser emisora de todos e cada un dos documentos que se escriben para a "gobernación del reino" e a de ser receptora daqueloutros que se enviaban ao rei ou aos órganos de administración do reino. Consecuentemente, a chancelería é a única oficina que posúe os selos reais e con eles valida os documentos, logo do exame do chanceler e rexistro nos libros-rexistro polos escribáns. Este centralismo obrigará a ter unha serie de oficinas anexas á chancelería e de tipo subsidiario, todas elas localizadas na corte itinerante, pero diferenciadas pola súa función, xermes das secretarías da coroa, dende mediados do XIV.

O núcleo central da chancelería está formado polo chanceler, os notarios, os escribáns, os grossatores, os registratores e os seladores. Ao seu lado estarían as tres notarías (León, Castela e Andalucía), cun número indeterminado de escribáns, encargados da expedición de documentos, fundamentalmente de mercé, graza e goberno. A chancelería de xustiza, presidida polos alcaldes de corte cos seus correspondentes notarios e escribáns; e a de cá- 
mara, de carácter económico, presidida polo camareiro do rei e servida por notarios e escribáns. Como anexa a esta última estaría a chamada chancelería da puridade, non ben documentada no reinado. Había outras chancelerías menores: a da raíña e a dos infantes. Á fronte da primeira había un chanceler, con notarios e escribáns. A dos infantes só tiña notarios e escribáns. ¿Poderían ambas derivar das respectivas cámaras reais, o mesmo que a da puridade?

Pero ademais a obra lexislativa de Afonso X vai ocuparse do oficio, obrigacións e calidades que ha de ter o chanceler real. Segundo a Partida 14.18.13 é o magister sacri scrinii libellorum, coa misión de custodiar os selos do rei, as arcas e escritos da chancelería, e está á fronte dos notarios e escribáns da corte. É o segundo oficial da casa do rei, despois do capelán, o que ten o oficio da poridat. Debe ser de boa liñaxe, para que sempre teña vergoña de facer algo que estea mal; debe ter buen seso natural, para que saiba gardar as poridades do rei, amén doutras calidades (Partida 2.9.4, P. 4, 18, 13). Ademais debe coñecer ben o latín e o romance (Partida 2.9.4). Posúe unha inmunidade e unha responsabilidade, esta non ben determinada.

A chancelería de León, que é a que máis nos interesa, por ocuparse, cando menos teoricamente, dos asuntos de Galicia, desempéñaa o arcebispo de Santiago Xoán Arias (1255/11/3-1266/5/4). Á súa morte queda vacante e só en 1283 Pelayo Pelaez unirá as dúas chancelerías, León e Castela, co que se reafirma a supremacía castelá.

Dos notarios do reino de León só atopamos un galego ou relacionado con Galicia, o mestre Xoán Afonso (1259-¿1284?), sobriño do rei, posible colaborador na elaboración das Partidas, desde 1270 arcediago de Santiago, que máis tarde será chanceler con Sancho IV.

Dos outros cargos da chancelería net arios de cámara, notarios de xustiza (sempre laicos), escribáns grossatores (uns dependían directamente do rei e do chanceler e outros dos alcaldes, adiantados e camareiro maior do rei) — non nos consta con seguridade que ningún procedera ou tivera algunha relación con Galicia, xa que a segunda parte do seu apelido se refire ao seu lugar de nacemento ou procedencia e non aparece ningún topónimo galego. Cos escribáns registratores, e cos seladores e visadores ful timos que interveñen na confección do documento- sucede o mesmo.

Sancho IV, durante a rebelión contra o seu pai (1282-1284), mantén a estrutura do seu proxenitor, aínda que non nomea os chanceleres maiores de Castela e León, pero si existe un chanceler maior de Castela e León, o infante don Pedro, seu irmán; tampouco hai notarios maiores, pero si unha persoa que como tal leva a cabo a revisión documental, o abade de Valladolid Gómez García, despois notario maior de León. Ordenan a redacción dos documentos a Pedro Sánchez, que logo será escribán de cámara dependente 
directamente do rei; Roy Martínez, sancristán de Valladolid, e Juan Martínez (¿rexistración?). A súa prudencia fai que non emita privilexios rodados, pero si emprega o selo de chumbo para validar privilexios non rodados e cartas chumbadas, pero só despois da deposición do seu pai, en abril de 1282.

Xa rei de pleno dereito, impón unha política fiscal reformada xa iniciada con Afonso X e reorganiza o funcionamento da cámara real, á fronte da cal está un notario maior da cámara ata as Cortes de Haro de 1288, e dende aquela un camareiro maior, que actúa baixo a supervisión do mordomo maior. Non aparece o arcebispo de Santiago como chanceler de León, pero si o de Toledo, xa en 1286, Gonzalo García Gudiel, que dende finais de 1290 será de Castela, León e Andalucía; e máis tarde, ata finais de 1290, o bispo de Palencia don Juan Alfonso, co que segue a ausencia de próceres leoneses na corte, tanto máis galegos, como sucede na chancelería da "poridat". Notarios maiores de León son o abade de Valladolid, separado por traizón en xuño de 1286, e dende setembro o bispo de Astorga, antes notario de Andalucía. De Castela, Fernán Pérez de Maimón ata 1290, bispo de Sigüenza e deán de Sevilla. A finais de 1289 o bispo de Palencia Juan Alfonso. De Andalucía Martín, bispo de Calahorra (1286); Xoán, bispo de Tui (1286-1290); volve Martín (1290). As tres unidas: Martín González, bispo de Astorga (1290-fin reinado). Da cámara do rei: Gil, bispo de Badaxoz (1285-1288). Outros subalternos mandan escribir o documento, quizais substituíndo ao chanceler e aos notarios maiores. Hai dúas fórmulas diversas: La mandó fazer, refírese á actio; la fizo escrivir, á conscriptio. Tamén hai revisores e rexistradores. Coas Cortes de Haro (1288) prodúcese unha novidade na cámara real, a aparición do camareiro como responsable da administración do patrimonio real, rendas e dereitos reais, que ordena a expedición de documentos. ao seu lado están o mordomo e o despenseiro maior.

De Fernando IV, simplemente por cronoloxía (1295-1312), interésanos a minoría (6\1295-12\1301). O chanceler do rei é Roy Pérez de Atienza, o de León, o arcebispo de Santiago frei Rodrigo González, e o de Castela, o de Toledo. Os notarios: de León, o bispo de Astorga; de Castela, un leigo, un alcalde do rei; de Toledo, Fernán Gómez durante todo o reinado; de Andalucía varias persoas ao longo do período.

Pasemos agora ao documento privado (diplomaticamente), o máis importante para nós tanto dende o punto de vista diplomático e xurídico coma do lingüístico. As súas orixes en época medieval hai que poñelas na aparición do notarius publicus, no que Bono Huerta chama "renacimiento legal del siglo xII" (1979: 165ss). En Galicia xa atopamos notarios que seguen a canonística do XII, unida a París, e a decretalística romana. Isto demóstrao o primeiro notario de Galicia que atopamos en Santiago en 1162, Lupus Arie, de nomeamento episcopal. ¿Por onde entrou o concepto do notario como 
persoa pública que redacta o documento público? Atreveriámonos a dicir que polo Camiño de Santiago, onde chegan tanto a influencia francesa como a romana e conflúen na escola episcopal compostelá que se remonta ao século anterior e que se pon ao día. E non é de estrañar que precisamente sexa na outra cidade galega episcopal máis próxima ao camiño onde apareza o segundo, Lugo, co subdiácono e cóengo Pelagius Sebastiani, do bispo e curia, que segundo os datos actuais comeza a súa carreira en 1193. Xa case quince anos máis tarde, en 1207, achamos o primeiro de Ourense, Arias Miguez, tamén do bispo e curia. Xa con posterioridade atópanse notarios nos mosteiros galegos.

Pero ademais hai outras categorías de notarios, os reais, que desenvolve Afonso X sobre todo nas Partidas, que Bono (1979) considera "la más completa formulación en la materia [notariado] en Occidente", pero que antes xa aparece no Fuero Real (1255) e o Espéculo (1260). A xuízo de Lucas (1989: 331-480), a institución do notariado atopámola en Galicia con posterioridade ao Fuero Reall ${ }^{12}$. Finalmente están os notarios do Concello, que "cabe suponer que ... consideraron parte de sus derechos el nombramiento de escribanos o notarios, como responsables de la administración de los documentos, por delegación del rey" (Lucas Álvarez 1989: 343-344) ${ }^{13}$.

Outros documentos que poderiamos considerar aquí serían os episcopais e os xudiciais, pero non imos tratar deles xa que falta un estudo serio de ambos os dous para este momento, a pesar de que varios autores xa os trataron con anterioridade (Riesco Terrero 1995, Prieto Morera 1992, Sanz Fuentes / Calleja Puerta 2004: 113-136).

12. O primeiro que atopamos en Galicia, segundo Lucas (1989: 337), é o de Asma, Xoán Domínguez (1257-1300); en Santiago non asoman ata 1279, con Iohannes Martini (Lucas 1989: 441). Porén, xa atopamos con anterioridade un en 1240 na área de Pontedeume: vid. Fernández de Viana y Vieites / González Balasch (1999: 139-141).

13. No traballo no que nos fundamentamos deste autor dá como probables os primerios en Ribadavia, Martinus Alviti, "scriptor Burgi" (1223/12/19) e Iohannes Nunonis o Munonis, "notarius Burgi" (1233/3/00), 435, e xa sen dúbida en Monforte a Iohannes Martini, "notarius concilii Montis Fortis" (1243-1246) (Lucas 1989: 398). 


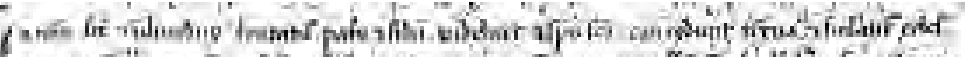

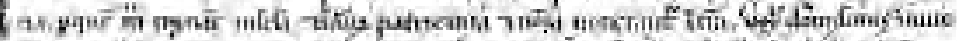

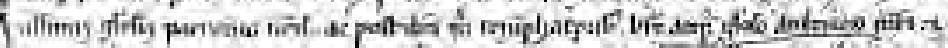

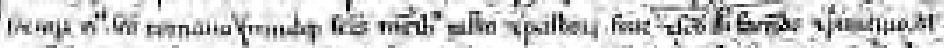

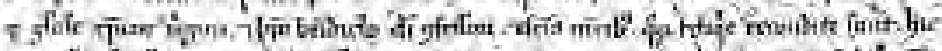

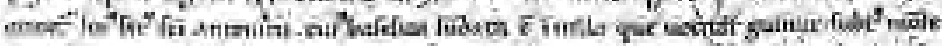

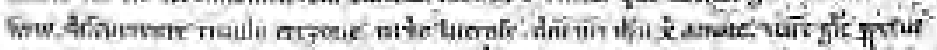

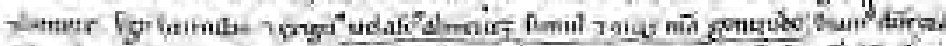

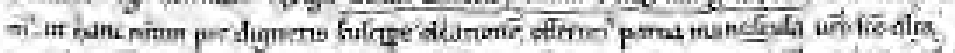

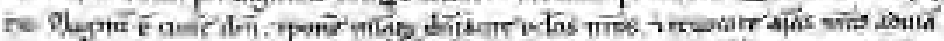

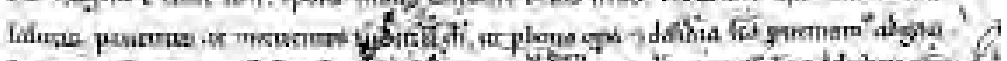

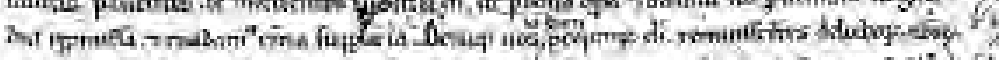

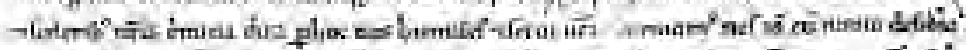

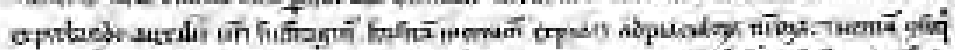

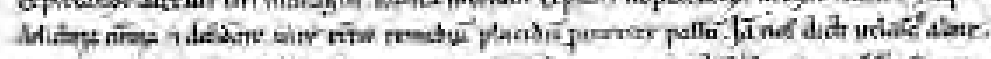

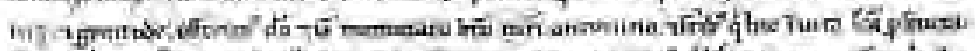

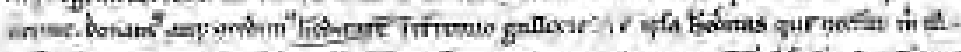

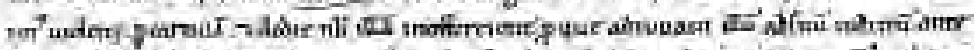

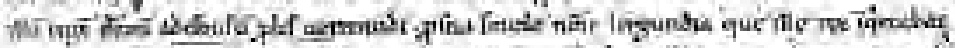

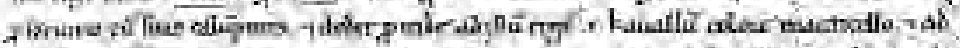

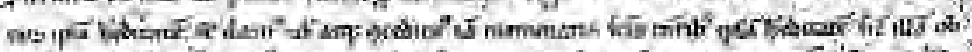

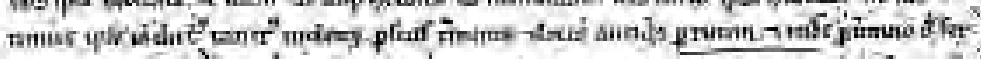

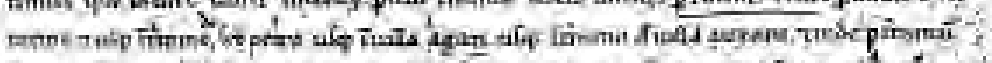

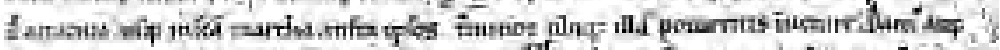

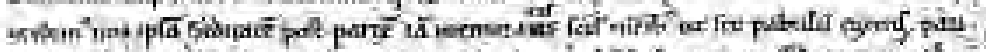

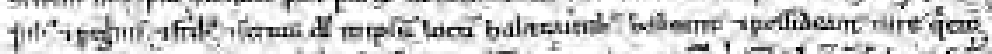

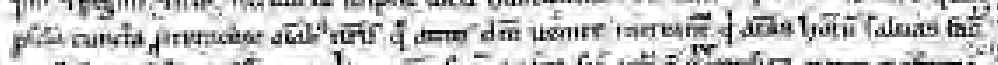

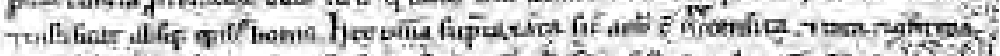

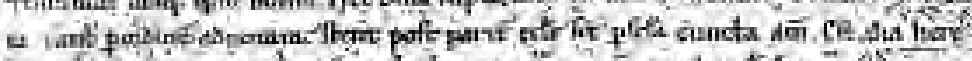

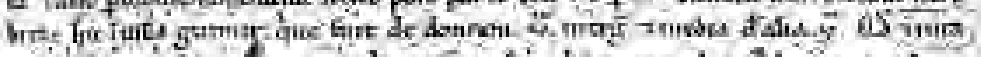

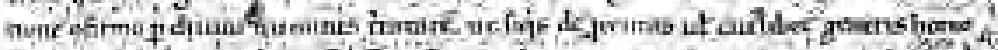

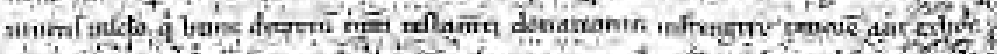
vong of

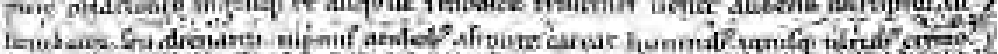

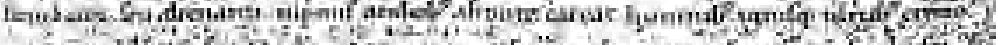

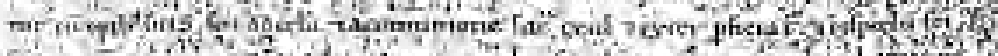

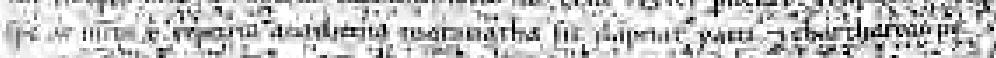

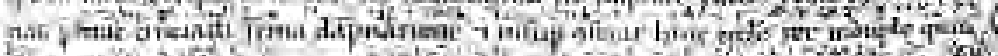

[1200]

Carolina códices, Santiago, Arquivo Histórico Universitario de Santiago, fol. 10r.

Tumbo de Samos, escrito en 1200 


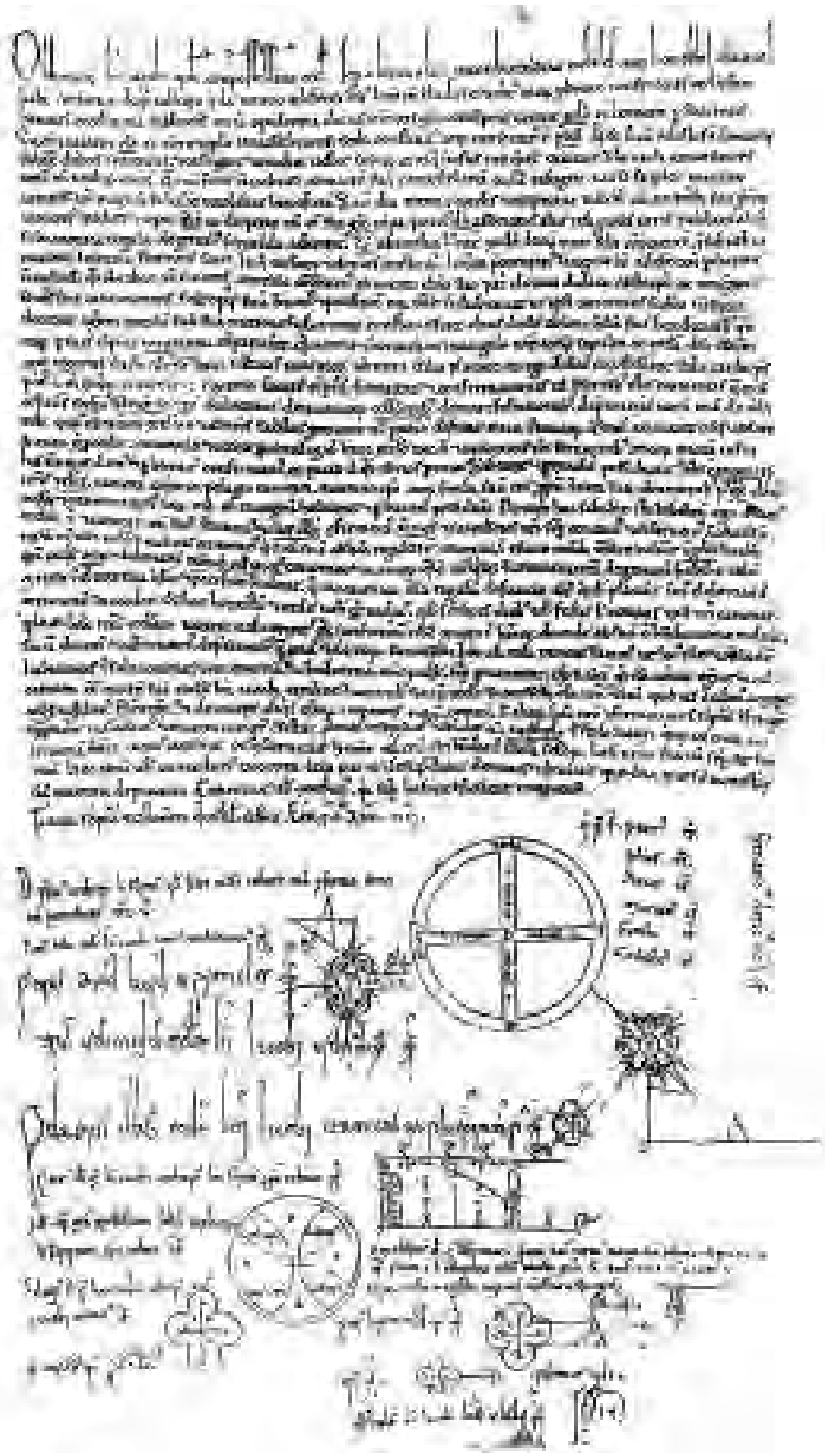

1136, setiembre, 1

Minúscula carolina documental, Santiago, Archivo Parroquial de Sar, $n^{\circ} 2$. 


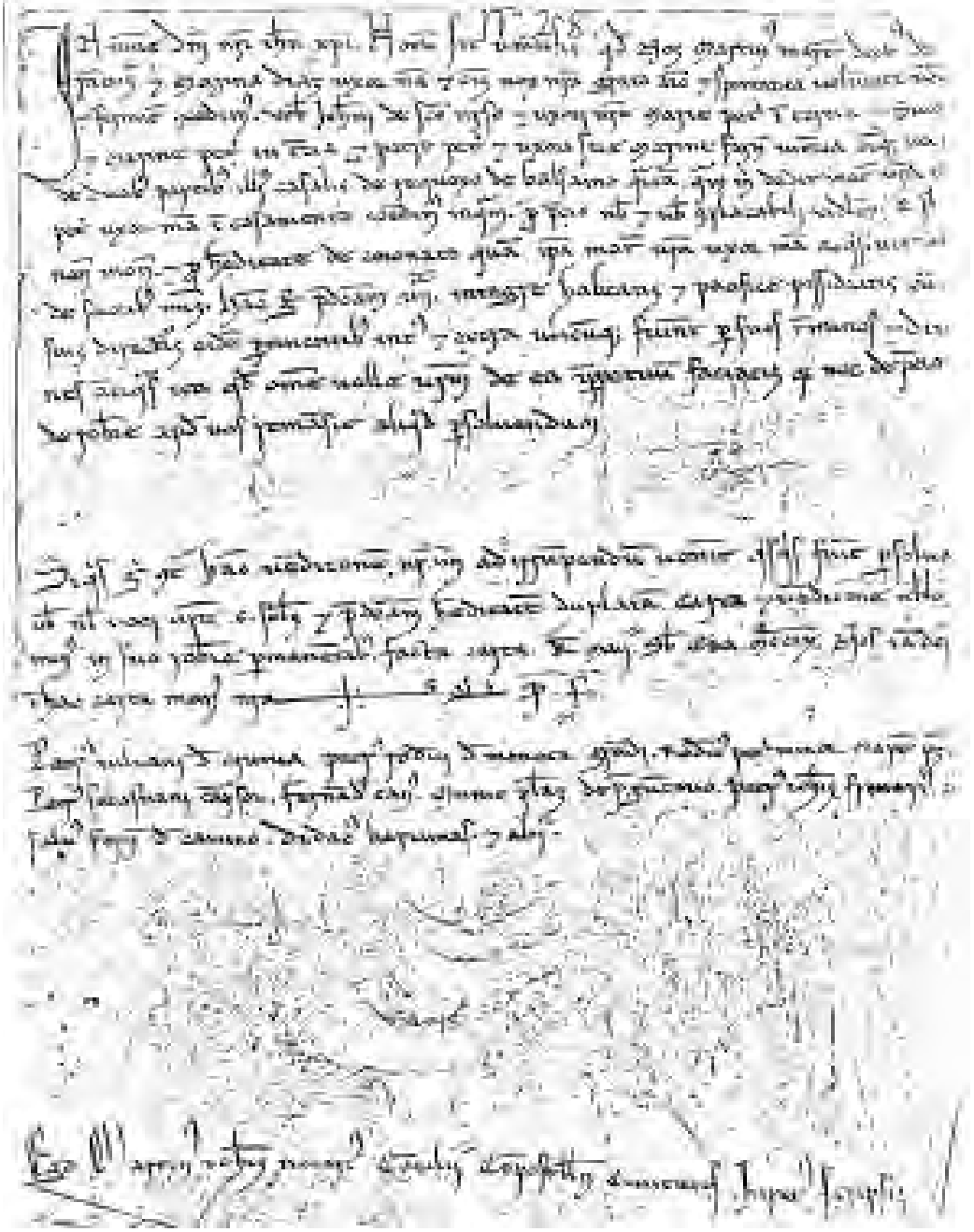

1222, mayo, 1 .

Minúscula diplomática, Santiago, Arquivo de San Francisco, Santa Clara, 1/7. 
of 1 m

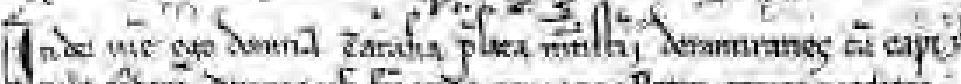

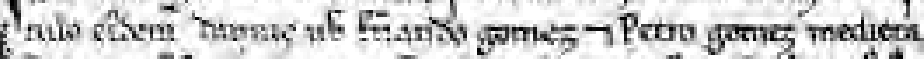

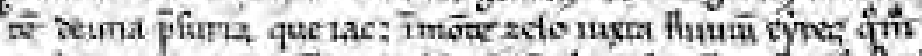

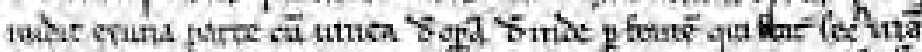

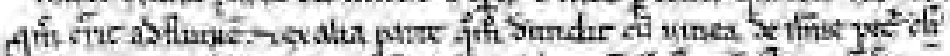

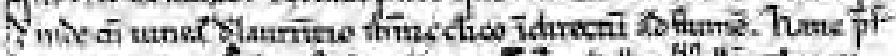

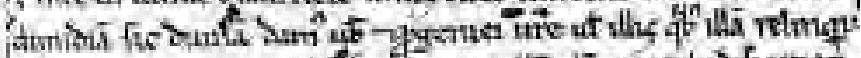

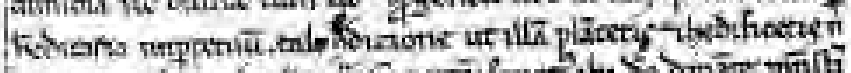

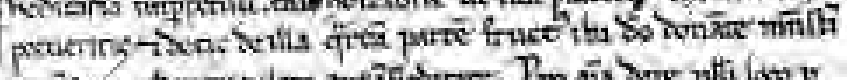

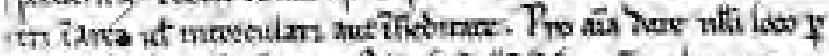

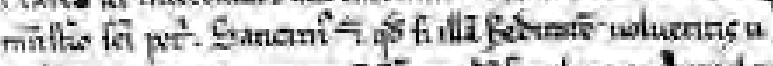

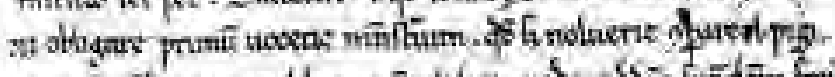

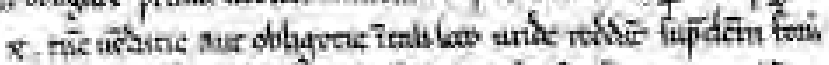

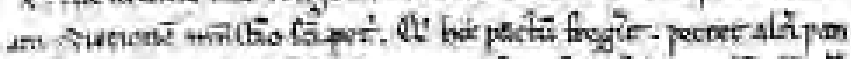

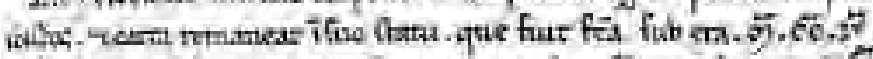

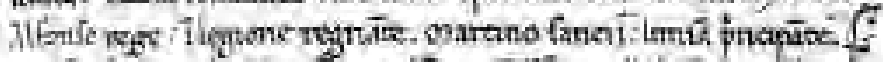

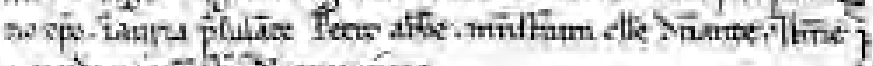

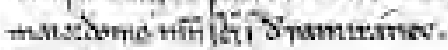
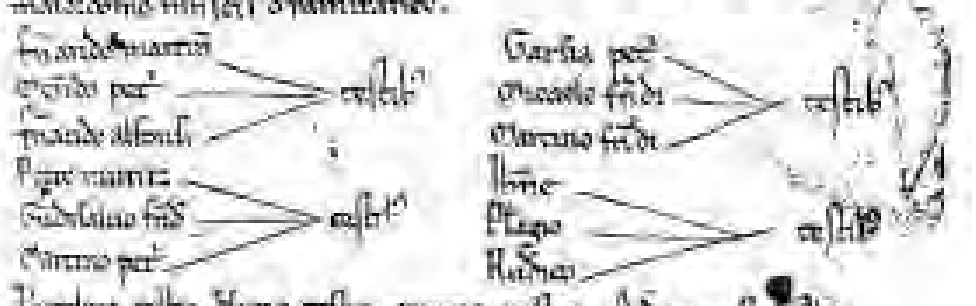

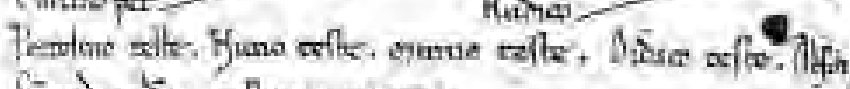

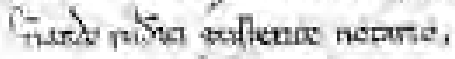

[h. 1222-1223]

Gótica textual, Madrid, AHN, Coruña, Antealtares, 522/14. 


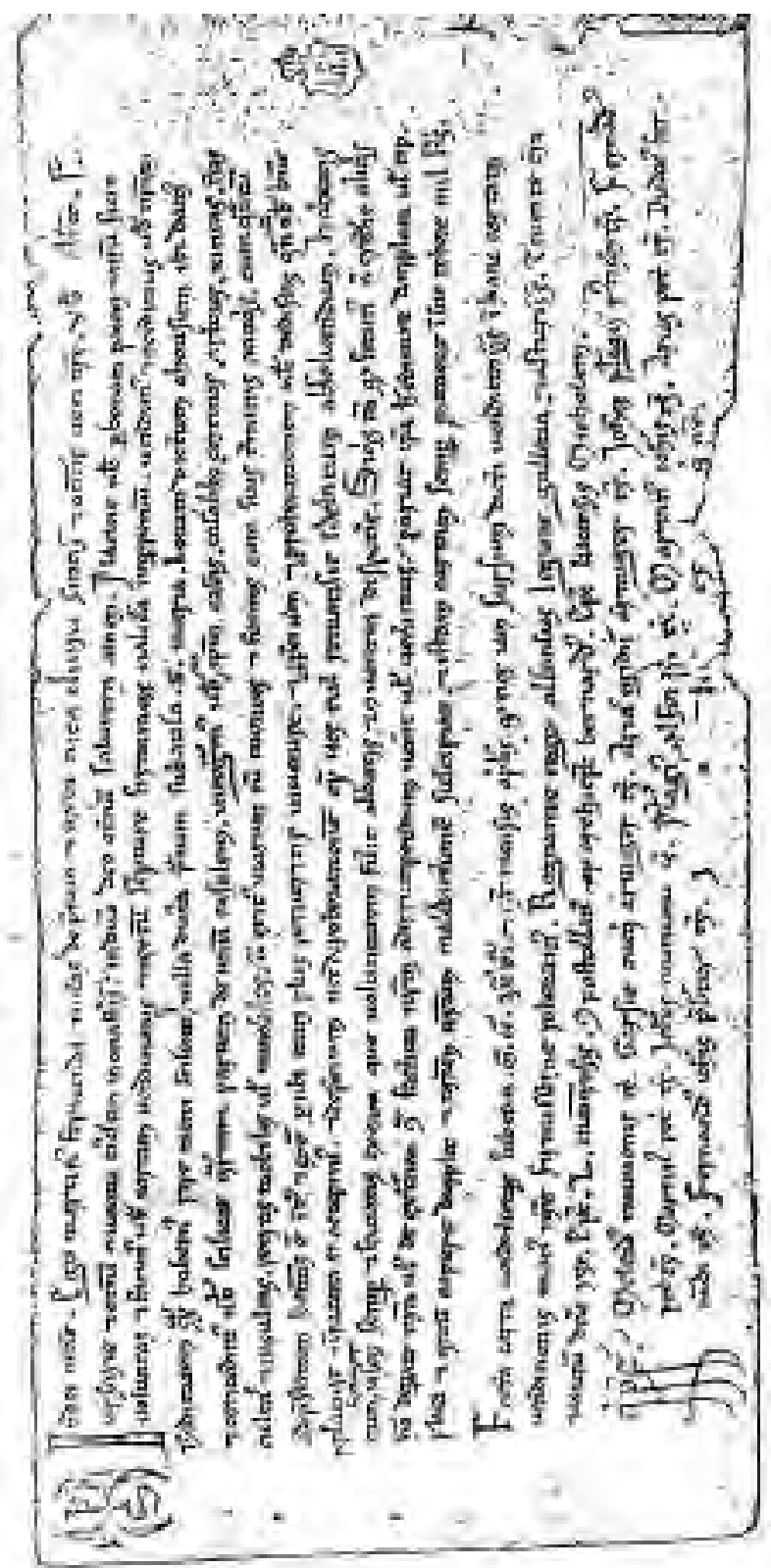

1228, abril.

Minúscula diplomática caligráfica, Madrid, AHN, Ourense, Oseira, 1516/13. 


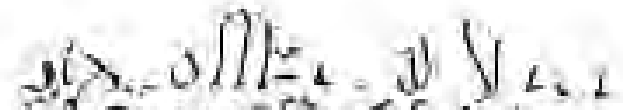

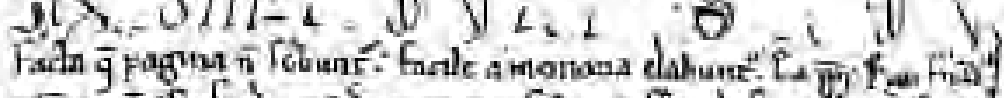

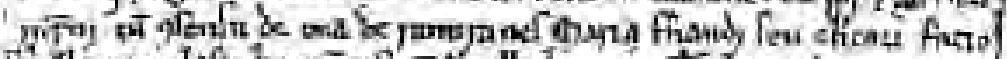

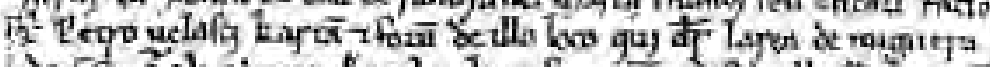

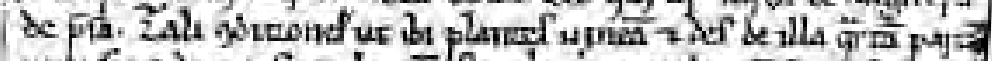

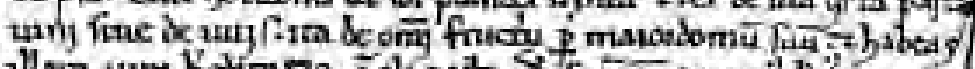

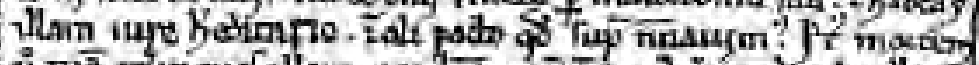

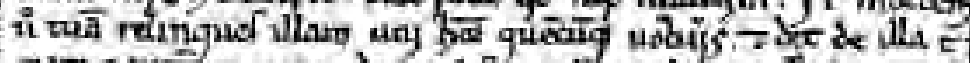

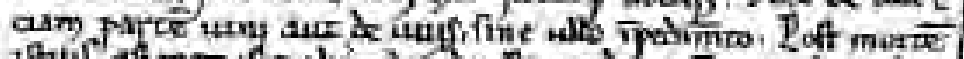

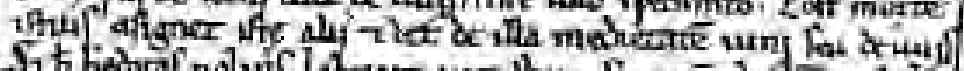

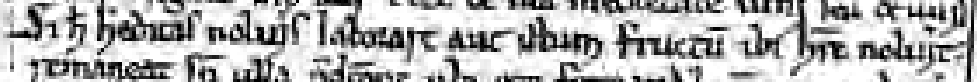

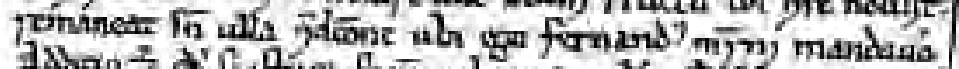

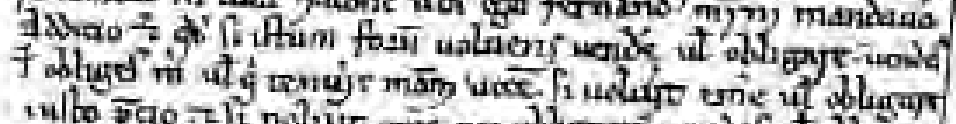

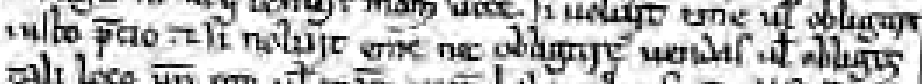

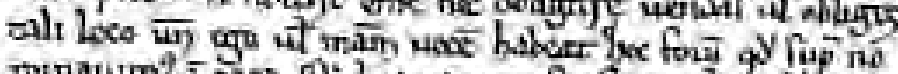
тy

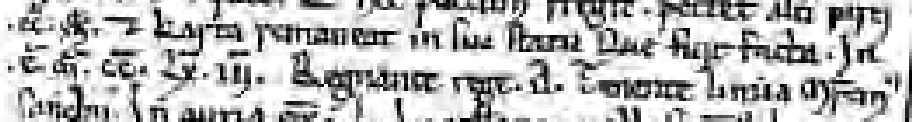

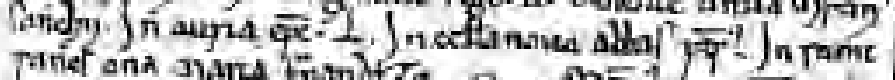

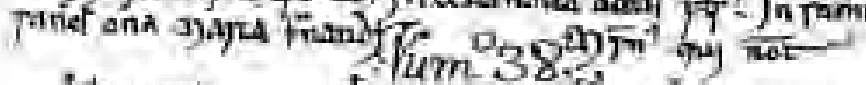

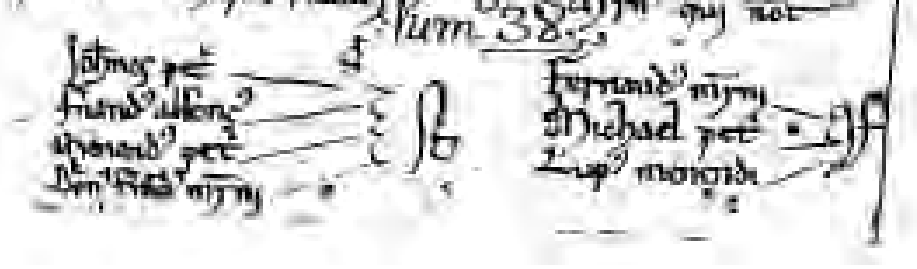

Minúscula diplomática caligráfica, Madrid, AHN, Clero, Coruña, Antealtares, 


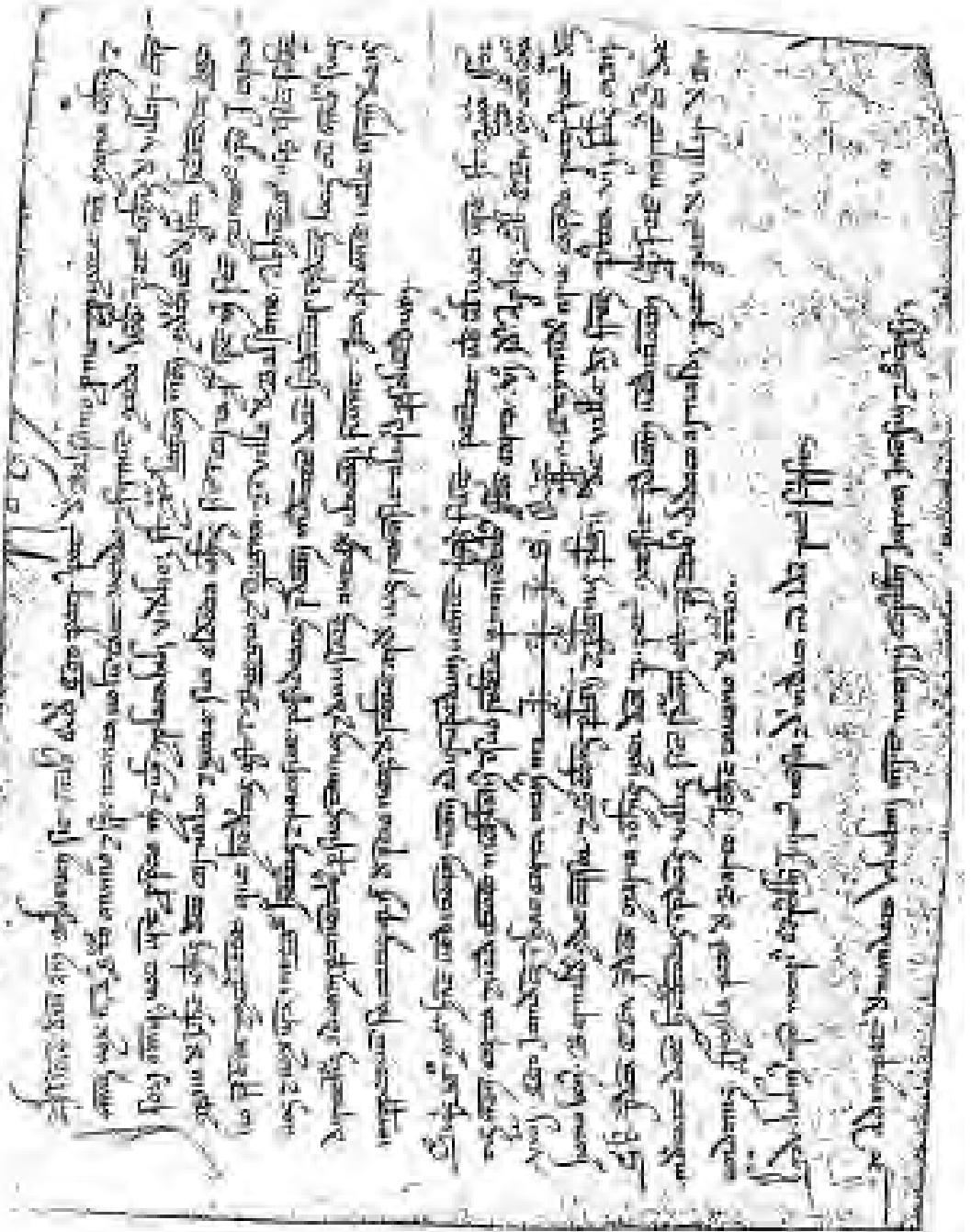

1241, abril, 8-25.

Minúscula diplomática caligráfica, Santiago, Arquivo de San Francisco, Santa Clara. 


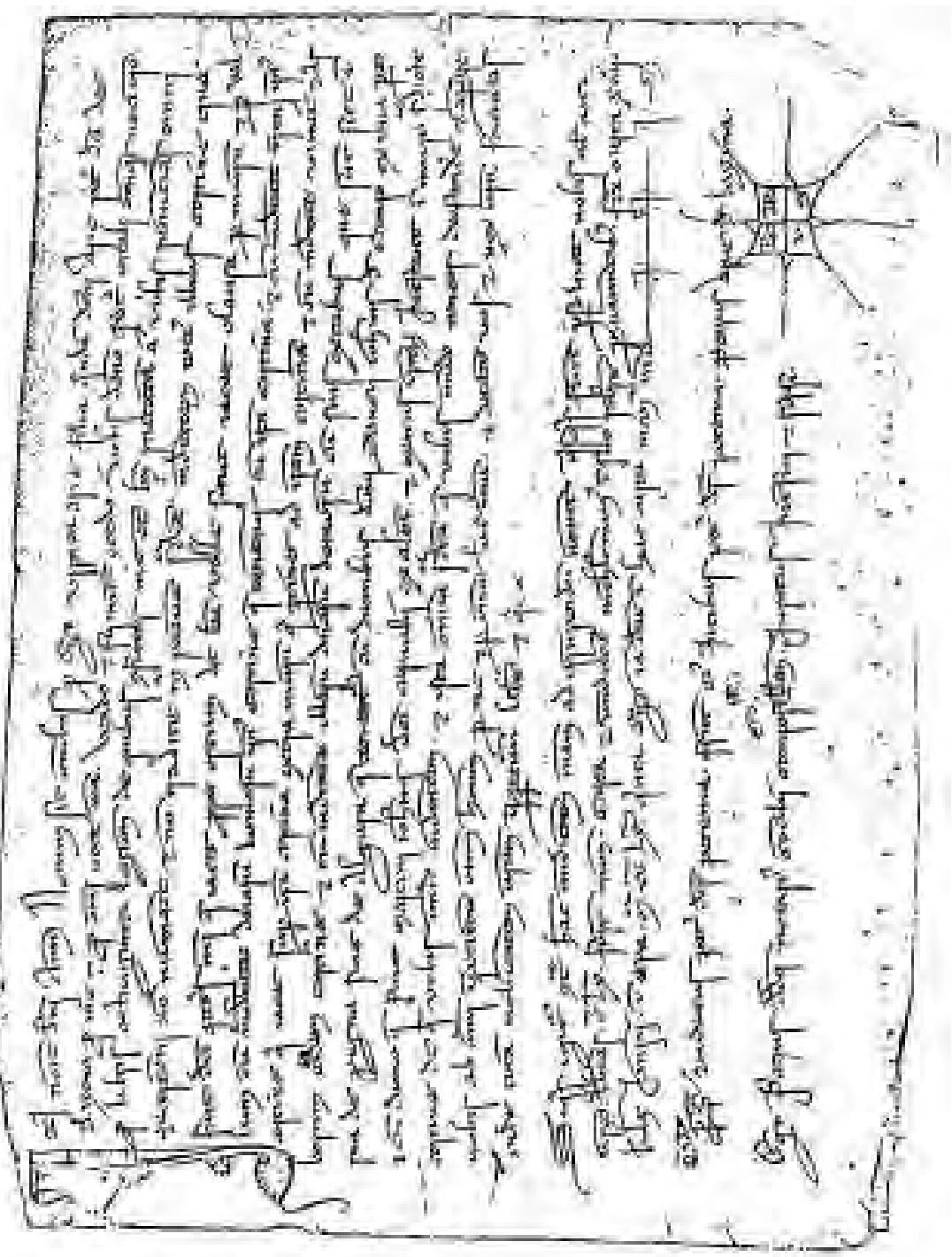

1257, diciembre, 26.

Minúscula diplomática currens > cursiva, Santiago, Arquivo de San Francisco,

Santa Clara. 
bes

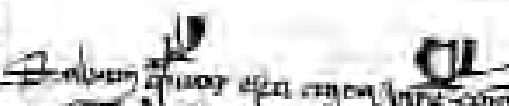

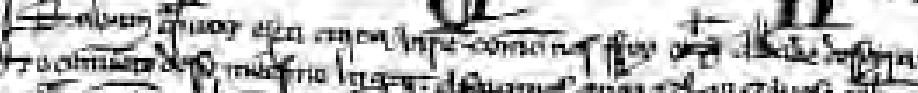

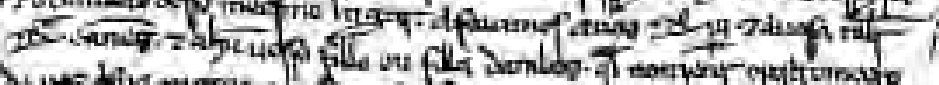

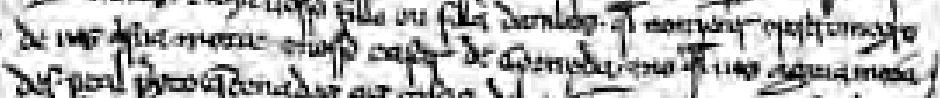

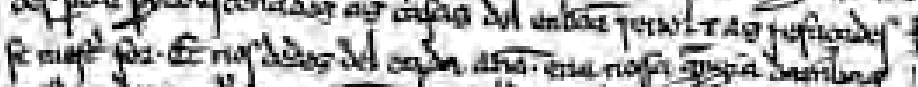

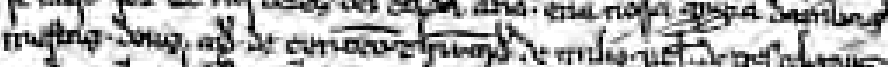

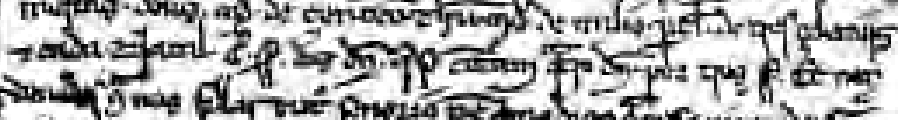
Qute

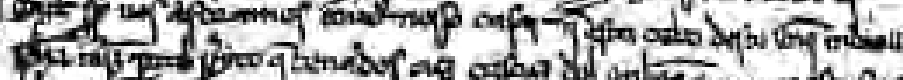

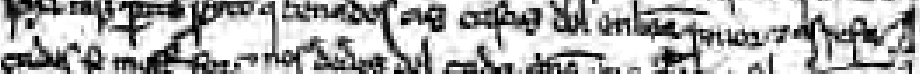

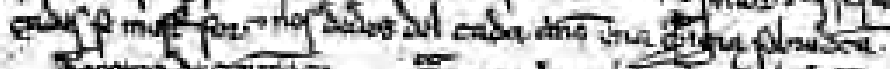

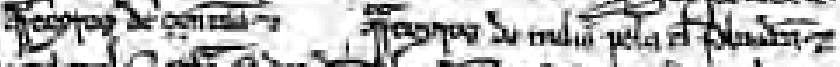

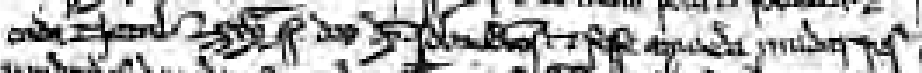

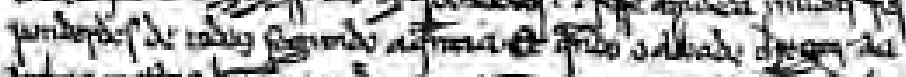

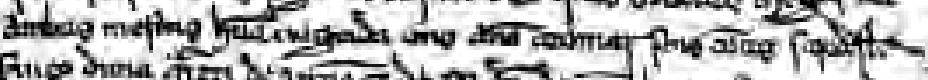

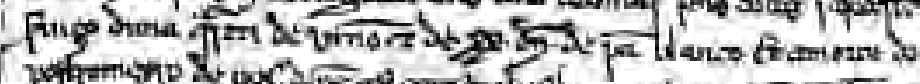

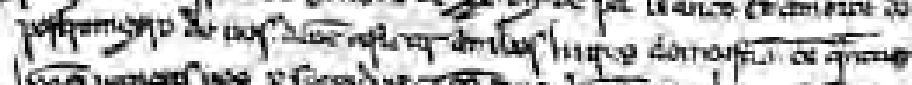

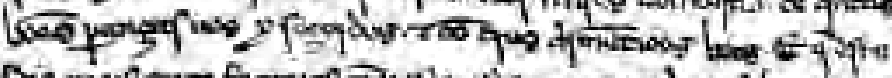

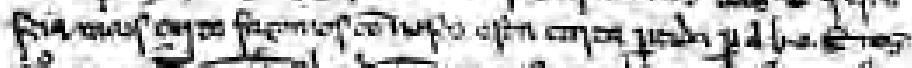

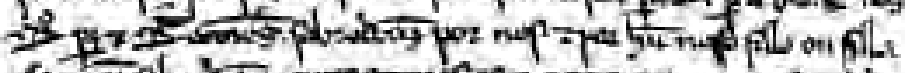

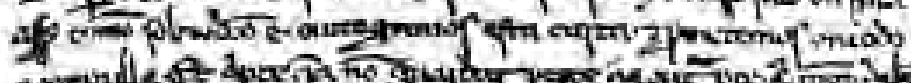

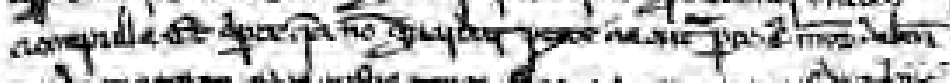

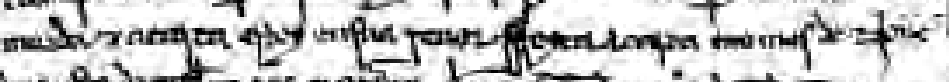

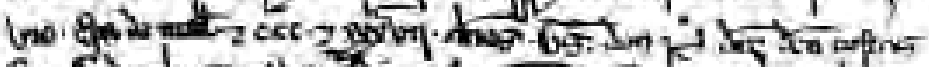

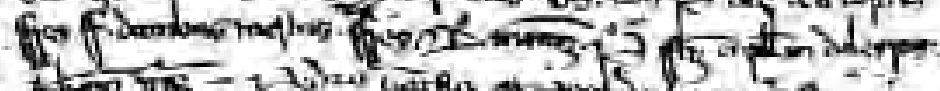

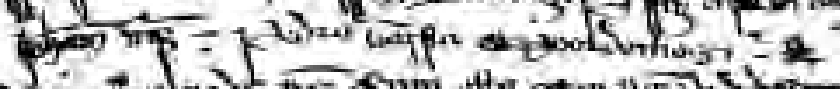
स्व

1299, noviembre.

Gótica currens documental, Madrid, AHN, Ourense, Oseira, 1538/12. 